Article

\title{
Evaluating the Improvement of Sustainability of Sports Industry Policy Based on MADM
}

\author{
Kuang-Hua Hu ${ }^{1}$, Fu-Hsiang Chen ${ }^{2, *}$ and Gwo-Hshiung Tzeng ${ }^{3}$ \\ 1 Department of Accounting, Nanfang College of Sun Yat-sen University, Wenquan Town, Conghua, \\ Guangzhou 510970, China; khhu0622@gmail.com \\ 2 Department and Graduate School of Accounting, Chinese Culture University, No. 55, Hwa Kang Rd., \\ Yang Ming Shan, Taipei 11114, Taiwan \\ 3 Graduate Institute of Urban Planning, National Taipei University, 151, University Rd., San Shia District, \\ New Taipei City 23741, Taiwan; ghtzeng@mail.ntpu.edu.tw \\ * Correspondence: cfh@faculty.pccu.edu.tw; Tel.: +886-2-2861-0511 (ext. 35525)
}

Academic Editor: Giuseppe Ioppolo

Received: 11 April 2016; Accepted: 22 June 2016; Published: 28 June 2016

\begin{abstract}
The influence of globalization on sports has turned out to be a popular issue widely discussed by researchers. Improvement to the sustainability of sports industry policy is an important and challenging issue, and related are inherently multiple attribute decision making (MADM) problems that can be strategically important to economic systems. The purpose of this study is to set up a new sustainability sports industry policy evaluation model that addresses the main causal factors and amends the priorities. A MADM model is combined with DEMATEL, DANP, and VIKOR for the evaluation and improvement of the sustainability of sports industry policy. The improvement priorities according to the domain expert interviews are in the following order: promotion and assistance of government policy $(A)$, sports venues and facilities $(D)$, enterprise sponsorship of sports quality $(E)$, expert human resources $(B)$, and finally sports competitions and events $(C)$.
\end{abstract}

Keywords: sustainability; sports industry policy; improvement strategies; MADM; DEMATEL; VIKOR

\section{Introduction}

With rising national income, advancements in technology, and growing health awareness, sports and recreation have become star industries around the world [1,2]. The sustainable development of the international sports industry following economic development [3] shows that sports and recreation have gradually become daily necessities for modern citizens, leading to changes in lifestyle as well as growing health and sport awareness. Skinner and Zakus (2008) [4] indicated that sport-based programs could be a vehicle to contribute to the development of social capital inclusion and can be made available in target communities. World Health Organization (WHO) proposed "Move for Health" as a slogan and emphasized the importance of fitness and a healthy lifestyle [5]. The United Nations General Assembly adopted a special resolution (No 58/5) on sports and physical education, noting that they are a major tool, not only for health and physical development, but also for social and cultural development [6]. Therefore, creating a healthy lifestyle and promoting national sports participation have become a common goal in advanced countries in this century.

The era of mass sports has arrived, as sports has become a modern national requirement in daily life, for the reason that sport development-related activities have strikingly increased [7]. Local physical activity programs with national support in Finland have been successful in promoting health and in increasing the sporting population [8]. Shilbury, Sotiriadou and Green (2008) [9] advocated that strengthening a sports development strategy and its sustainable value can drive the interest of 
the people in sports participation and correct social health ethos, building a quality sports culture for the future. Therefore, it is necessary to provide a safe and comfortable sports environment that gives citizens the opportunity to complete activity and to meet the needs of their physical and mental exercise. However, further improvement is needed in personnel fostering, competition, and incentives of related sport industry policies to enhance the sustainability of national sports and to forge a national sports culture.

Sports and government public policy in many countries have been inextricably linked, through the support of sports development-related activities. The sports development policy of elite and mass participation in Australia and Finland has formed a conceptual framework [10]. In Australia, a large number of prominent sports systems relating to active coaches, elite athletes, participants, volunteers, and support groups have been developed [11]. The United Kingdom is the cradle of modern sports policy [12]. Its physical framework is mainly controlled by the markets and non-government organizations, with only about $30 \%$ from government action [13]. The country's sports policies cover a wide range, including sports infrastructure, schools having all levels of sports programs, community sports, and an Olympic field (Hall) recycling facility, which take into account both the development goals of competitive sports and mass sports [14]. The United States and Germany are the traditional top world sports powers. Sports and the livelihood of people involved are integrated as a characteristic of the U.S. sports policy. The development strategies of government leading sports, based on the general public and social organizations, have gradually formed a perfect sports system and mature sports industry market [15]. Germany's sports policy is based on a sports club system and a core of mass sports since 1990, promoting the development of sports throughout the country; and for competitive sports, school sports and mass sports have played a significant role [16]. Obviously, sustainability of sport policies involves a wide range of issues [17]. In formulating policies, authorities must take into account many factors/indicators. However, how to use limited resources effectively is an important principle for creating robust sustainable sports industry policy.

Prior studies on the improvement of sustainability of sports industry policy primarily put more focus on elite and mass participation [9]. In this study, the sustainability of sports industry policy indicates that evaluation and improvement of related affairs (factors) in the industry's development can help achieve the objectives of national sports participation sustainability. In general, the assumption is that the improvement of sustainability of sports industry policy factors is a linear regression or an estimation of descriptive statistics on sample-level observables [10,18], and investigations are conducted with conventional statistical techniques, such as univariate statistical methods, factors analysis, discrimination analysis, and logit and probit models. These conventional statistical methods, however, have some restrictions in assumptions, such as the linearity, normality, and independence of sport industry variables. Given that the assumptions are often inconsistent with improving the means of sustainability of sports industry policy factors, the methods have intrinsic limitations in terms of effectiveness and validity. Those unrealistic assumptions cause limitations in exploring the entwined relationships of complex problems in practice.

Few studies have examined how to improve sustainability of sports industry policy. As can be seen from the above, the formulation of such sustainability is a multiple criteria decision making (MADM) problem. However, in the real world, the related variables are not independent, as an influential interrelationship (dependence and feedback) exists among them, and thus MADM approaches can be applied to solve this problem. This method has been widely applied in various fields [19-23], but has been seldom been used by sports industries. Therefore, in order to improve sustainable sports industry policy, in this study, we consider all related variables (called dimensions/criteria) for the global sustainable development of sports industry policy. The new method is then demonstrated based on an empirical case study of Taiwan's sports policy, with a focus on how to improve the influence and effects of a sustainable sports industry policy. 


\section{Literature Review}

With economic growth and improvement in the quality of life, the importance of sports for the health and fitness of people has been gradually recognized around the world [24]. Ever since relevant governmental authorities have integrated their sports policy with culture, recreation, and tourism industries, it has seen robust development and has drawn increasing attention in recent years. The highly developed European and North American countries have devoted extensive resources to the promotion of their sports industry policy. Many studies have discussed sports industry policy $[7,9,10,25]$, presenting many factors affecting its sustainable development. A survey of the literature and in-depth interviews with sports experts show five major perspectives (or dimensions) as follows.

\subsection{Promotion and Assistance of Government Policy}

The gradual emergence of sports related policy is also driving the development of related industries and expanding the job market. National sports policies have driven people's participation in sports and physical activity, laying a strong foundation for the sports industry [26]. Examples include building a good environment conducive to sports development, actively enhancing competitiveness within the international community, and constructing a high-quality sports and recreational environment for people [27]. The Sports Affairs Council (SAC), under the auspices of Taiwan's Executive Yuan, promulgated the Sports Industry Development Act on 6 July 2011 [28]. Based on the regulations and recommendations made by experts and scholars, this act facilitates the promotion and implementation of government policies as potential factors affecting the sustainable development of the national sports industry, in the form of incentives for athletes, counseling and incentives for the development of all types of sports, the promotion of sporting events and international sports exchanges [29], and the establishment of preferential financing for the sports industry.

\subsection{Expert Human Resources}

The specialization and development of expert human resources are at a very early stage in the process of sports development. As suggested by Wolsey, Minten and Abramset (2012) [30], effective human resource management can boost the capacity of fostering various talents in the sports and recreation industries. Feng (2011) [31] indicated that good human resources and a humanistic environment would accelerate sustainability of sports development. It is also imperative to supply sports development with a sufficient number of elite athletes by means of school education and enterprise or social training [32], as sports education institutions can train large numbers of professionals to engage in competitive sports [33]. Apart from this, the industry-academic cooperation [34] model helps integrate students' knowledge and real practices to help bridge the gap between the school curriculum and requirements of the job market. Workplace participation can help enhance the quality and practical experience of professional talents [35], while the implementation of a professional certification system [36] can help guarantee service quality. Government sports officials should establish a centralized institution to standardize and conduct frequent athletics coaching, and furthermore an athletics coaches' licensing board should be formed to ensure high standards in coaching and offer licenses to qualified coaches. This would help to provide an effective professional verification and screening mechanism that could improve the quality of the sports industry sustainable development.

\subsection{Sports Competitions and Events}

One of the key factors to the sports industry sustainable development is organizing and holding sports events [37]. Positive benefits arise for a city to host sport-related events in terms of heightened visibility, enhanced city image, increased visitation and tourism revenue, expanded sport participation, and growth in local sports [25]. After the recent Olympic and Paralympic Games in London, the 
number of people in England playing sports delivered a sustained increase [38]. Sports events not only provide venues for sports, but also create many surrounding economic benefits [2,39-41]. Bondarenko (2013) [42] and Inoue, Mahan III and Kent (2013) [43] also pointed out that sports venues and professional sports teams have a positive impact on the development of regional economics. Jewell, Simmons and Szymanski (2014) [44] showed that professional sports have become the economic and cultural focus of several U.S. cities. Most studies present that holding sports competitions and events will lead to significant economic benefits, not to mention sustainable development of the sports; however, Beijing's 2008 Olympic Games had a negative economic impact on tourism in China, as noted by Shina, Adam and Chris (2011) [45].

\subsection{Sports Venues and Facilities}

Sports venues are a pre-requisite for the sustainable development of the sports industry. The Australian government has spared no efforts in supporting the sports industry. The government has provided sufficient funding for both indoor and outdoor sports facilities, particularly the construction of sports fields and stadiums. The Australian government believes that people's participation in sports not only has positive effects on health and quality of life, but also brings about direct and indirect economic and social benefits, which are welcomed by the general public [46]. Wicker, Prinz and Von Hanau (2012) [18] suggested that sport infrastructure has a significant impact on sport participation. With improvements in people's living standards and health consciousness, there is an increased demand for public sports venues and facilities $[47,48]$. If a sports venue conforms to the requirements for an international sports event, then a country can bid for large-scale international sports events, in order to directly promote "brand awareness" of the country or city [49], thus indirectly creating economic benefits. According to Davies (2005) [50], the building of sports venues in the United Kingdom has achieved the objective of stimulating the economy. From a management perspective, sports venues can be categorized into public sports venues, school sports venues, and commercial sports venues. Public-private partnerships have been introduced by governments as innovative ways to create an effective governance structure and ensure realistic risk allocation [51]. Public sports venues are mainly used by the public to participate in sports. The facilities in these venues have to meet the needs of the general public in order to increase people's interest in participating in sports. However, public sports venues are not located in each region. School sports venues are normally adjacent to communities at convenient locations with a high usage rate. School sports venues are an important place for people to participate in sports, which can drive the sustainable development of the related sports industries. Commercial sports venues are constructed to satisfy different needs and to make up for the deficiency of public sports venues [52], making them also one of the driving forces behind sports.

\subsection{Enterprise Sponsorships of Sports}

The government and private business should cooperate to effectively promote the sports development strategy and action plan in creating a sound sports industry policy on an existing basis. The sustainable development of sports requires multi-dimensional assistance-one important channel of which is the promotion of sports and competitions through sports sponsorships [53]. As far as enterprises are concerned, the sponsorship of sports events can enhance corporate image, visibility, and benefits $[54,55]$ as well as increase consumer confidence in products [56]. In brief, it serves as another form of advertising. From the perspective of sports groups, sponsorship can give them access to high-quality equipment, facilities, human resources, venues, and funds, creating a win-win situation for both enterprises and sports groups [57]. Enterprise sponsorships of organizations, sports events, individuals, or teams [58,59] facilitate the development of the sports. The value of national sporting success from investing in national teams and athletes also leads to positive social effects [18]. 


\subsection{Discussion}

After reviewing the above sports industry policy studies, the focus appears to be on a unilateral consideration, as those factors have not exhaustively improved sports industry sustainable development. In order to help government and related sports industry corporates to avoid suffering an inefficiency loss, it is necessary to provide an extraordinarily comprehensive scope and to develop a model that is able to improve sustainability of sports industry policy. Therefore, this paper proposes a novel hybrid model for sustainability of sports industry policy formulation and improvement.

\section{Building a New Decision Model for Sustainability of Sports Industry Policy Formulation}

The new hybrid MADM model herein is developed based on the aforementioned studies and is deemed a fitting method for the assessment of sustainability of sports policy development and can be used as a reference for decision-makers to improve performance in each criterion. This section includes four subsections: first, the data collection process is described; second, the DEMATEL (Decision-Making Trial and Evaluation Laboratory) technique is introduced and how to build an INRM (influential network relation map) is described; third, the study introduces how to find the influential weights of DANP (DEMATEL-based ANP) based on a total influence matrix of DEMATEL; and fourth, we describe how to use the modified VIKOR (VlseKriterijumska Optimizacija I Kompromisno Resenje) method to implement and amend gaps for each criterion and to propose a strategy for improving sustainability of sports industry policy.

\subsection{Data Collection}

Based on the literature review noted above and according to interviews with five scholars in sports related departments, three government officials in sports administrations, and two managers from private sports venues, we summarize the lists of factors that can enhance the effects of improving sustainability of sports industry policy as the basis of the pre-test questionnaire. In order to ensure effective pairwise comparisons and good consistency, a limited number of factors in a single construct have been developed by Saaty (1996) [60]. The relative importance criteria were found by asking the aforementioned experts to answer the pre-test questionnaire. The importance value of each criterion can be obtained by using pre-test questionnaires with a scale ranging from 0 points (low importance) to 10 points (high importance) and by selecting the importance criteria (based on triangular fuzzy numbers and with a mean of 8 and above). The results are shown in Table 1.

Table 1. Sustainability of sports industry policy evaluation factors.

\begin{tabular}{ccc}
\hline Dimensions/Criteria & Descriptions & Reference \\
\hline \multicolumn{2}{c}{$\begin{array}{c}\text { Promotion and Assistance of Government Policy }(A) \\
\text { for sports industries }\left(a_{1}\right)\end{array}$} & $\begin{array}{c}\text { Include the provision of counseling and incentives for activities } \\
\text { promoted by all sports-related industries (Article } 8 \text { of the Sports } \\
\text { Industry Development Act) }\end{array}$ \\
\hline $\begin{array}{c}\text { [26,28,61] } \\
\text { Promotion of international sports } \\
\text { exchanges }\left(a_{2}\right)\end{array}$ & $\begin{array}{c}\text { Include sports exchange and cooperation agreements concluded } \\
\text { between the government and other countries, exchange and } \\
\text { cooperation agreements signed between civil sports groups and } \\
\text { civil sports groups of other countries, participation in important } \\
\text { international conferences in relation to international sports groups. } \\
\text { Bid for acting as the head of an international sports organization; } \\
\text { invite the head of an international sports organization. }\end{array}$ \\
\hline
\end{tabular}


Table 1. Cont.

\begin{tabular}{|c|c|c|}
\hline Dimensions/Criteria & Descriptions & Reference \\
\hline \multicolumn{3}{|c|}{ Expert Human Resource $(B)$} \\
\hline $\begin{array}{l}\text { Establishment of a professional certification } \\
\text { management system by government }\left(b_{1}\right)\end{array}$ & $\begin{array}{l}\text { Establish and manage government certification system; } \\
\text { put into place a complete and careful professional sports } \\
\text { certification review system. }\end{array}$ & [36] \\
\hline Training of expert human resources $\left(b_{2}\right)$ & $\begin{array}{l}\text { Utilize school, enterprise or social channels to cultivate } \\
\text { professional talent. }\end{array}$ & {$[30,31]$} \\
\hline Formation of industry-academic cooperation $\left(b_{3}\right)$ & $\begin{array}{l}\text { Form cooperative relationships between } \\
\text { industries and academia. }\end{array}$ & [32-34] \\
\hline \multicolumn{3}{|c|}{ Sports Competitions and Events $(C)$} \\
\hline Organizing and holding national sports events $\left(c_{1}\right)$ & Regularly hold national sports events. & {$[25,37]$} \\
\hline $\begin{array}{l}\text { Organizing and holding international sports events } \\
\qquad\left(c_{2}\right)\end{array}$ & Regularly hold international sports events. & {$[2,39,40]$} \\
\hline Promotion of professional sports games $\left(c_{3}\right)$ & To hold professional games over a long period of time. & {$[42,43]$} \\
\hline \multicolumn{3}{|c|}{ Sports Venues and Facilities $(D)$} \\
\hline Widespread public sports venues, facilities $\left(d_{1}\right)$ & $\begin{array}{l}\text { Universalize public sports venues, facilities and rank } \\
\text { these venues and facilities according to merits. }\end{array}$ & [18] \\
\hline $\begin{array}{l}\text { Operating and management of public } \\
\text { sports venues }\left(d_{2}\right)\end{array}$ & $\begin{array}{l}\text { Evaluate appropriateness of the operation and } \\
\text { management of public sports venues (including OT, ROT, } \\
\text { BOT) to prevent these venues from being under-utilized. }\end{array}$ & [49-51] \\
\hline $\begin{array}{l}\text { Offering government incentives for the private sector } \\
\text { to invest, build or operate sports venues }\left(d_{3}\right)\end{array}$ & $\begin{array}{l}\text { Any government incentive measure to support the } \\
\text { construction of private sports venues. }\end{array}$ & [52] \\
\hline \multicolumn{3}{|c|}{ Enterprise Sponsorships of Sports $(E)$} \\
\hline Sponsorship of sports groups $\left(e_{1}\right)$ & $\begin{array}{l}\text { Long-term support by enterprises of sports groups or } \\
\text { organizations in various forms, including cash, goods and } \\
\text { materials, equipment, technologies and services. }\end{array}$ & [57] \\
\hline Sponsorship of sports events $\left(e_{2}\right)$ & $\begin{array}{l}\text { Practical support from enterprises for specific sports } \\
\text { events, championships or friendly competitions. }\end{array}$ & [53-55] \\
\hline Sponsorship of sports teams $\left(e_{3}\right)$ & $\begin{array}{l}\text { Enterprises' long-term sponsorship of sports teams by } \\
\text { offering assistance for training or during games. }\end{array}$ & {$[58,59]$} \\
\hline
\end{tabular}

After applying the results of the initial questionnaire, the DEMATEL, DANP, and VIKOR methods were combined and incorporated into the final questionnaire design. A total of 20 questionnaires were handed out mainly for the analysis of interactions between the dimensions of sport industry policies and criteria (including six government officials from sports administrations, six managers from private sports venues, and eight scholars in sports-related departments).

\subsection{DEMATEL Technique for Building an Influential Network Relation Map}

The DEMATEL technique was first developed by the Geneva Research Centre between 1972 and $1976[62,63]$ for the purpose of showing a network relation diagram, a structural model for understanding specific societal problems. The DEMATEL technique involves follow steps: The first step constructs the system with n elements/criteria and develops the evaluation scale using pairwise comparison for aspects/criteria to determine the degree of influence on an integer scale. The second step calculates the initial matrix to directly obtain the influential matrix A. The second step finds the normalized matrix D such that the sums of at least one column or row, but not all, equal one. Then, in the third step, the total influential matrix T can be obtained and the INRM can be drawn [64-66]. The DEMATEL technique can be summarized as follows.

Step 1: Calculate the direct influence-relation average matrix using scores. Assume that there are K number of sport experts and n number of factors (called criteria), and pairwise comparison of two factors is required. An integer score of 0, 1, 2, 3 or 4 are given, representing the range from "absolutely no influence (0)" to "very high influence (4)" and indicate the degree of influence of factor/criterion $i$ 
on factor/criterion $j$. The questionnaire by each expert forms a $n \times n$ non-negative matrix $\boldsymbol{Y}^{k}=\left[y_{i j}^{k}\right]$, $1 \leqslant k \leqslant K$, where $\boldsymbol{Y}^{1}, \ldots, \boldsymbol{Y}^{k}, \ldots, \boldsymbol{Y}^{K}$ are the influence matrices by the $K$ experts. Thus, an $n \times n$ average matrix $G$ is constructed with the Equation (1):

$$
\boldsymbol{G}=\left[\begin{array}{ccccc}
g_{11} & \cdots & g_{1 j} & \cdots & g_{1 n} \\
\vdots & & \vdots & & \vdots \\
g_{i 1} & \cdots & g_{i j} & \cdots & g_{i n} \\
\vdots & & \vdots & & \vdots \\
g_{n 1} & \cdots & g_{n j} & \cdots & g_{n n}
\end{array}\right]
$$

The average scores of the $K$ experts are $g_{i j}=\frac{1}{R} \sum_{k=1}^{K} y_{i j}^{k}$. The average matrix $G$ indicates the degree of influence with a dimension/criterion by effects on another as well as degree of influence it receives from others.

Step 2: Derive the normalizing direct influence-relation average matrix. The normalized initial direct influence-relation matrix $Z$ can be obtained from normalizing the average matrix $G$. Matrix $Z$ can be derived through Equations (2) and (3) whereby all principal diagonal criteria are equal to zero:

$$
s=\min \left\{\frac{\boldsymbol{Z}=s \cdot \boldsymbol{G}}{\max _{1 \leqslant i \leqslant n} \sum_{j=1}^{n} a_{i j}}, \frac{1}{\max _{1 \leqslant j \leqslant n} \sum_{i=1}^{n} a_{i j}}\right\}
$$

Step 3: Attain the total influence-relation matrix. Once the normalized direct-influence matrix $Z$ is obtained, the total influence-relation matrix $T$ of INRM can be obtained from Equation (4), where $I$ represents the identity matrix.

$$
\begin{aligned}
& \boldsymbol{T}=\boldsymbol{Z}+\boldsymbol{Z}^{2}+\ldots+\boldsymbol{Z}^{q} \\
& =\boldsymbol{Z}\left(\boldsymbol{I}+\boldsymbol{Z}+\boldsymbol{Z}^{2}+\ldots+\boldsymbol{Z}^{q-1}\right) \\
& =\boldsymbol{Z}\left(\boldsymbol{I}+\boldsymbol{Z}+\boldsymbol{Z}^{2}+\ldots+\boldsymbol{Z}^{q-1}\right)(1-\boldsymbol{Z})(1-\boldsymbol{Z})^{-1} \\
& =\boldsymbol{Z}(I-\boldsymbol{Z})^{-1}, \lim _{q \rightarrow \infty} \boldsymbol{Z}^{q}=[0]_{n \times n}
\end{aligned}
$$

where $\boldsymbol{T}=\left[t_{i j}\right]_{n \times n}, i, j=1,2, \ldots, n$. Each row sum and column sum of the total influence-relation matrix $T$ are found using Equations (5) and (6).

$$
\begin{gathered}
\boldsymbol{d}=\left(d_{i}\right)_{n \times 1}=\left[\sum_{j=1}^{n} t_{i j}\right]_{n \times 1}=\left(d_{1}, \ldots, d_{i}, \ldots, d_{n}\right)^{\prime} \\
\boldsymbol{r}=\left(r_{j}\right)_{n \times 1}=\left(r_{j}\right)_{1 \times n}^{\prime}=\left[\sum_{i=1}^{n} t_{i j}\right]_{1 \times n}^{\prime}=\left(r_{1}, \ldots, r_{j}, \ldots, r_{n}\right)^{\prime}
\end{gathered}
$$

where $d_{i}$ is the sum of a row in the total influence-relation matrix $T$, which represents the total effects (both direct and indirect) of factor $i$ on the other factors. Similarly, $r_{j}$ is the column sum in the total influence-relation matrix $T$, which represents the total effects (both direct and indirect) of factor $j$ received from the other factors. Thus, when $i=j,\left(d_{i}+r_{i}\right)$ provides an index of the strength of the total influences given and received; that is, $\left(d_{i}+r_{i}\right)$ indicates the degree of importance that factor $i$ plays in the system. In addition, $d_{i}-r_{i}$ provides an index of the degree of the cause of total influences. If $\left(d_{i}-r_{i}\right)$ is positive, then factor $i$ is a net causer, and if $\left(d_{i}-r_{i}\right)$ is negative, then factor $i$ is a net receiver. 


\subsection{Find the Influential Weights of DANP Based on the Total Influence Matrix of DEMATEL}

Not only is the DEMATEL technique used to construct the interactive relationship among the various aspects/criteria but it can also be used to seek the most accurate influential weights. The characteristics of the influential weights are applied based on the DEMATEL-based ANP to solve these types of problems. This study yields more practical results in the real world problem. Based on the influence relation matrix $\mathrm{T}$ (including $\boldsymbol{T}_{c}$ by criteria and $\boldsymbol{T}_{D}$ by dimensions, and $\boldsymbol{T}_{c}^{\alpha}$ and $\boldsymbol{T}_{D}^{\alpha}$ being shown the normalized influence relation matrix by criteria and dimensions) the DANP is used to construct the un-weighted and weighted (or normalized) $\boldsymbol{W}=\left(\boldsymbol{T}_{c}^{\alpha}\right)^{\prime}$ super-matrix. The influence weights of the criteria and dimensions are calculated by a sufficiently large multiplied itself power $g$, then the influence weights of DANP can be obtained with $\lim _{g \rightarrow \infty}\left(W^{\alpha}\right)^{g}$ (Chen, 2015 [67]; Chen, et al. 2015 [68]). The DANP is processed as shown in follows:

Step 4: Find $T_{C}$ (the matrix of criteria) and $T_{D}$. (the matrix of dimensions) Based on the total influence-relation matrix T using DEMATEL, $\boldsymbol{T}_{C}$ and $\boldsymbol{T}_{D}$ can be obtained as showing in Equation (7).

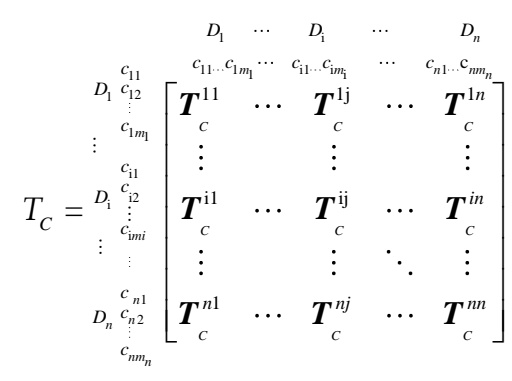

where $D_{n}$ is the $n$th cluster; $c_{n m}$ is the $m$ th criterion in the $n$th dimension; and $T_{C}^{i j}$ can show the influence degree of criterion $i$ affects criterion $j$.

Step 5: Find the un-weighted super-matrix $\boldsymbol{W}\left(=\left(\boldsymbol{T}_{c}^{\alpha}\right)^{\prime}\right)$. Normalize $\boldsymbol{T}_{C}$ by each dimension and $\boldsymbol{T}_{c}^{\alpha}$ can be found, as shown in Equation (8):

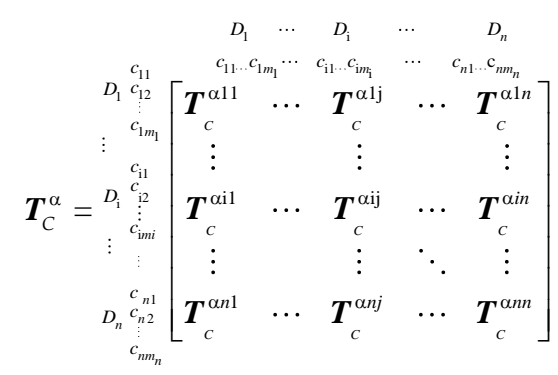

where $T_{C}^{\alpha}$ denotes the normalizing total influence-relation matrix, and $T_{c}^{\alpha 13}$ is derived from Equations (9) and (10). Similarly, $T_{c}^{\alpha n n}$ can be found.

$$
\begin{aligned}
& t_{i}^{13}=\sum_{j=1}^{m_{2}} t_{i j}^{13}, i=1,2, \cdots, m_{1}
\end{aligned}
$$

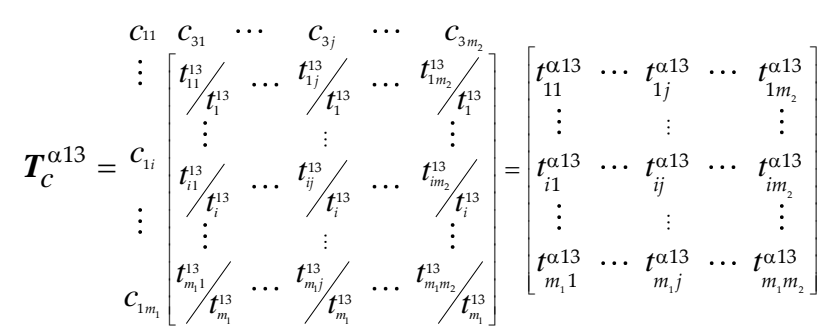


According to the interdependent relationship in clusters, the un-weighted super-matrix $W$ can be obtained by transposing the total matrix $\boldsymbol{T}_{C}^{\alpha}$, i.e., $\boldsymbol{W}=\left(\boldsymbol{T}_{C}^{\alpha}\right)^{\prime}$, as shown in Equation (11).

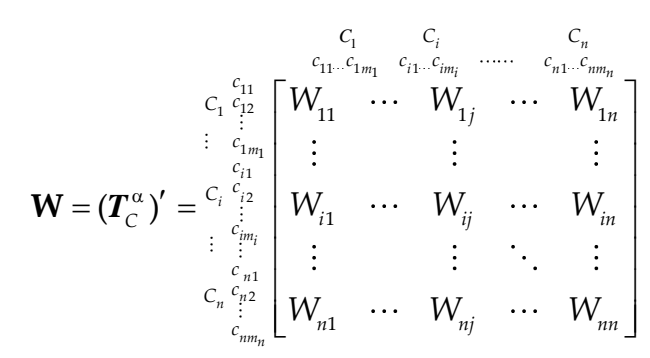

Step 6: Construct the weighted super-matrix $\mathbf{W}^{\alpha}$. The total influence-relation matrix of dimensions matrix $\boldsymbol{T}_{D}$ is given by Equation (12).

$$
\boldsymbol{T}_{D}=\left[\begin{array}{ccccc}
t_{11} & \cdots & t_{1 j} & \cdots & t_{1 n} \\
\vdots & & \vdots & & \vdots \\
t_{i 1} & \cdots & t_{i j} & \cdots & t_{i n} \\
\vdots & & \vdots & & \vdots \\
t_{n 1} & \cdots & t_{n j} & \cdots & t_{n n}
\end{array}\right]
$$

Based on the dimension, a new normalized total influence-relation matrix $T_{D}^{\alpha}$ can be obtained through normalized the total influence-relation matrix $\boldsymbol{T}_{D}$, as shown in Equation (13).

$$
\boldsymbol{T}_{D}^{\alpha}=\left[\begin{array}{ccccc}
t_{11} / t_{1} & \cdots & t_{1 j} / t_{1} & \cdots & t_{1 n} / t_{1} \\
\vdots & & \vdots & & \vdots \\
t_{i 1} / t_{i} & \cdots & t_{i j} / t_{i} & \cdots & t_{i n} / t_{i} \\
\vdots & & \vdots & & \vdots \\
t_{n 1} / t_{n} & \cdots & t_{n j} / t_{n} & \cdots & t_{n n} / t_{n}
\end{array}\right]=\left[\begin{array}{ccccc}
t_{11}^{\alpha D} & \cdots & t_{1 j}^{\alpha D} & \cdots & t_{1 n}^{\alpha D} \\
\vdots & & \vdots & & \vdots \\
t_{i 1}^{\alpha D} & \cdots & t_{i j}^{\alpha D} & \cdots & t_{i n}^{\alpha D} \\
\vdots & & \vdots & & \vdots \\
t_{n 1}^{\alpha D} & \cdots & t_{n j}^{\alpha D} & \cdots & t_{n n}^{\alpha D}
\end{array}\right]
$$

The weighted super-matrix $W^{\alpha}$ can be obtained using the normalized total influence-relation matrix $T_{D}^{\alpha}$ and the un-weighted super-matrix $W$, as shown in Equation (14).

$$
\mathbf{W}^{\alpha}=\boldsymbol{T}_{D}^{\alpha} W=\left[\begin{array}{ccccc}
t_{11}^{\alpha D} \times \boldsymbol{W}_{11} & \cdots & t_{j 1}^{\alpha D} \times \boldsymbol{W}_{1 j} & \cdots & t_{n 1}^{\alpha D} \times \boldsymbol{W}_{1 n} \\
\vdots & & \vdots & & \vdots \\
t_{1 i}^{\alpha D} \times \boldsymbol{W}_{i 1} & \cdots & t_{j i}^{\alpha D} \times \boldsymbol{W}_{i j} & \cdots & t_{j i}^{\alpha D} \times \boldsymbol{W}_{i j} \\
\vdots & & \vdots & & \vdots \\
t_{1 n}^{\alpha D} \times \boldsymbol{W}_{n 1} & \cdots & t_{j n}^{\alpha D} \times \boldsymbol{W}_{n j} & \cdots & t_{n n}^{\alpha D} \times \boldsymbol{W}_{n n}
\end{array}\right]
$$

Step 7: Calculate the limit super-matrix $\boldsymbol{W}^{\alpha}$. Based on the concept of Markov Chain, the limit super-matrix can be obtained through limit the weighted super-matrix by itself multiple times. Thus, the global priority vectors can be found by $\lim _{g \rightarrow \infty}\left(W^{\alpha}\right)^{g}$, called the DANP (DEMATEL-based ANP), where $g$ indicates any number for power.

\subsection{VIKOR Method for Ranking and Improving the Alternatives}

In reality though, decision makers often have to simultaneously manage several plans with conflicting and non-proportionate (trade-offs) criteria. It is important to diminish the gaps between real performance values and aspiration levels and then rank the gaps for improvement of projects/alternatives in order to obtain a higher benefit. Because these plans do not usually have 
the same criteria, they cannot be dealt with using the traditional method. To overcome this difficulty, Opricovic and Tzeng proposed a new VIKOR method to solve this problem [69]. VIKOR is a suitable method for solving MADM problems. According to modified VIKOR method for the normalized class distance function it is preferable to be near the aspiration level and far from the worst value [70]. Opricovic and Tzeng (2004) [71] proposed a compromise ranking method (VIKOR) as a suitable technique for implementation within MADM for the ranking and selection of alternatives. The modified VIKOR method can not only be applied to the ranking and selection of alternatives, but can also be applied to find improvement within each criterion. We describe the modified VIKOR method below.

Step 8: Find the positive-ideal solution and negative-ideal solution. Examine the best value $f_{j}^{*}$ (positive-ideal solution) and the worst value $f_{j}^{-}$(negative-ideal solution) of assessment criteria of sustainability of sports industry policy, which can be obtained using Equations (15) and (16).

$$
\begin{gathered}
f_{j}^{*}=\max _{k}\left\{f_{k j} \mid k=1,2, \ldots, m\right\}, f^{*}=\left(f_{1}^{*}, \ldots, f_{j}^{*}, \ldots, f_{n}^{*}\right) \text { (positive ideal solution) } \\
f_{j}^{-}=\min _{k}\left\{f_{k j} \mid k=1,2, \ldots, m\right\}, f^{-}=\left(f_{1}^{-}, \ldots, f_{j}^{-}, \ldots, f_{n}^{-}\right) \text {(negative ideal solution) }
\end{gathered}
$$

Step 9: Compute aspiration level and worst value. Replace the positive ideal solution and negative solution with the aspiration level and worst value, that is:

Aspiration level: $f^{\text {aspired }}=\left(f_{1}^{a s p i r e d}, \ldots, f_{j}^{a s p i r e d}, \ldots, f_{n}^{\text {aspired }}\right)$, where $f_{j}^{\text {aspired }}$ is the aspiration level or optimal value.

Worst value: $f^{\text {worst }}=\left(f_{1}^{\text {worst }}, \ldots, f_{j}^{\text {worst }}, \ldots, f_{n}^{\text {worst }}\right)$, where $f_{j}^{\text {worst }}$ is the worst value.

Step 10: Determine the mean group utility $S$ for the gap and maximal gap $Q$. These values can be computed using Equations (17) and (18).

$$
\begin{gathered}
S_{k}=L_{k}^{p=1}=\sum_{j=1}^{n} w_{j} r_{k j}=\sum_{j=1}^{n} w_{j}\left(\left|f_{j}^{\text {aspired }}-f_{k j}\right|\right) /\left(\left|f_{j}^{\text {aspired }}-f_{j}^{\text {worst }}\right|\right) \\
Q_{k}=\max _{j}\left\{w_{j}\left(\left|f_{j}^{\text {aspired }}-f_{k j}\right|\right) /\left(\left|f_{j}^{\text {aspired }}-f^{\text {worst }}\right|\right) \mid j=1,2, \ldots, n\right\}
\end{gathered}
$$

where $S_{k}$ represents the normalized ratio of distance to the aspiration level; it also indicates the synthesized/aggregated gap ratio for the criteria. On the other hand, $Q_{k}$ represents the normalized ratio of distance to the worst value; it also indicates the maximal gap in $j$ criteria for improvement priority. Here, $w_{j}$ represents the influence weights of the criteria obtained from DANP, and $r_{k j}$ represents the normalized gap of distance to the aspiration level, and we focus on how to minimize the gap $\left(r_{k j}\right)$ for the criteria $(\forall j$ and $j=1,2, \ldots, n)$.

Step 11: Obtain the comprehensive indicator $R_{k}$ for ranking and selection. The values can be computed by Equation (19).

$$
R_{k}=v\left(S_{k}-S^{*}\right) /\left(S^{-}-S^{*}\right)+(1-v)\left(Q_{k}-Q^{*}\right) /\left(Q^{-}-Q^{*}\right)
$$

where $S^{*}=\min _{k} S_{k}, S^{-}=\max _{k} S_{k}, Q^{*}=\min _{k} Q_{k}, Q^{-}=\min _{k} Q_{k}$, and $0 \leqslant v \leqslant 1$, where $v$ represents the weight on the strategy of maximum group utility, where $1-v$ indicates the weight on individual regret (maximal gap for priority improvement). Therefore, when $S^{*}=0$ and $Q^{*}=0$, and $S^{-}=1$ and $Q^{-}=1$, Equation (19) can be re-written as $R_{k}=v S_{k}+(1-v) Q_{k}$. When $v=1$, it indicates only consideration of minimization of the average gap. As $v=0$, it indicates only consideration of the maximum gap for improvement priority. The research processes are illustrated in Figure 1. 


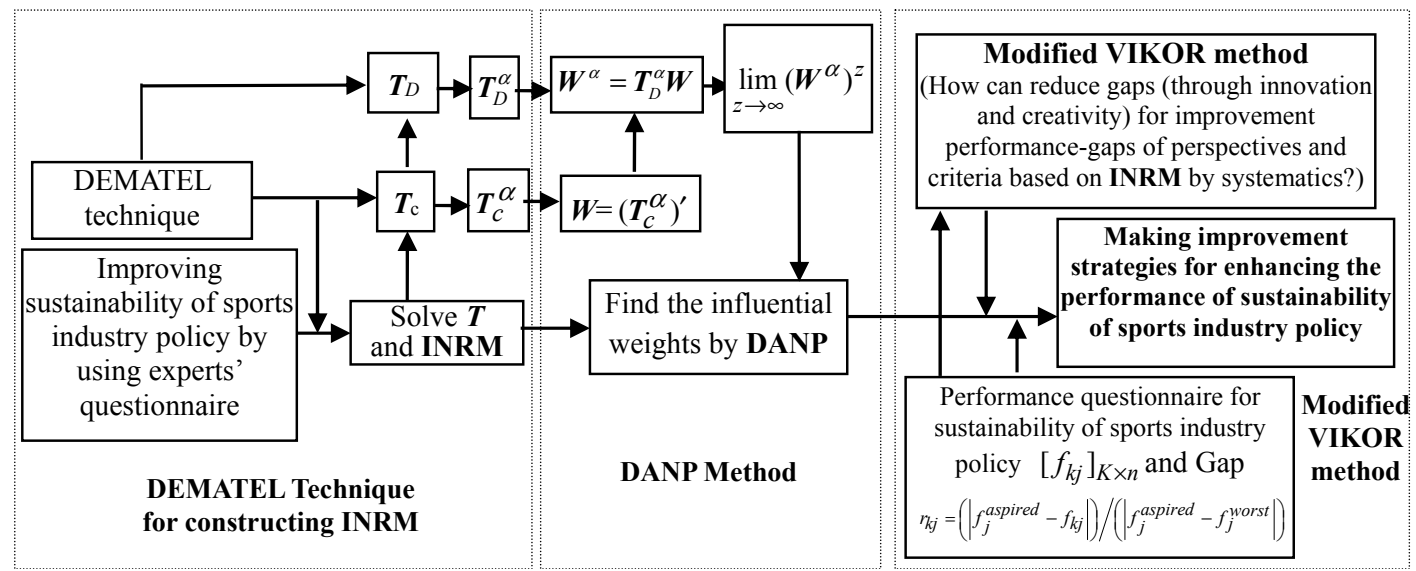

Figure 1. Model procedure for new multiple attribute decision making for sustainability of sports industry policy.

\section{An Empirical Case: An Improvement Plan for Taiwan's Sports Policy}

This section mainly discusses the current status and issues facing the sports industry policy of Taiwan as an example to demonstrate the suitability of the proposed new decision model to solve the problems arising from the complex dynamics in the real world. The priorities for improvement are based on the results of the questionnaire survey and evaluation process. A diagram of the empirical case study is illustrated in Figure 2.

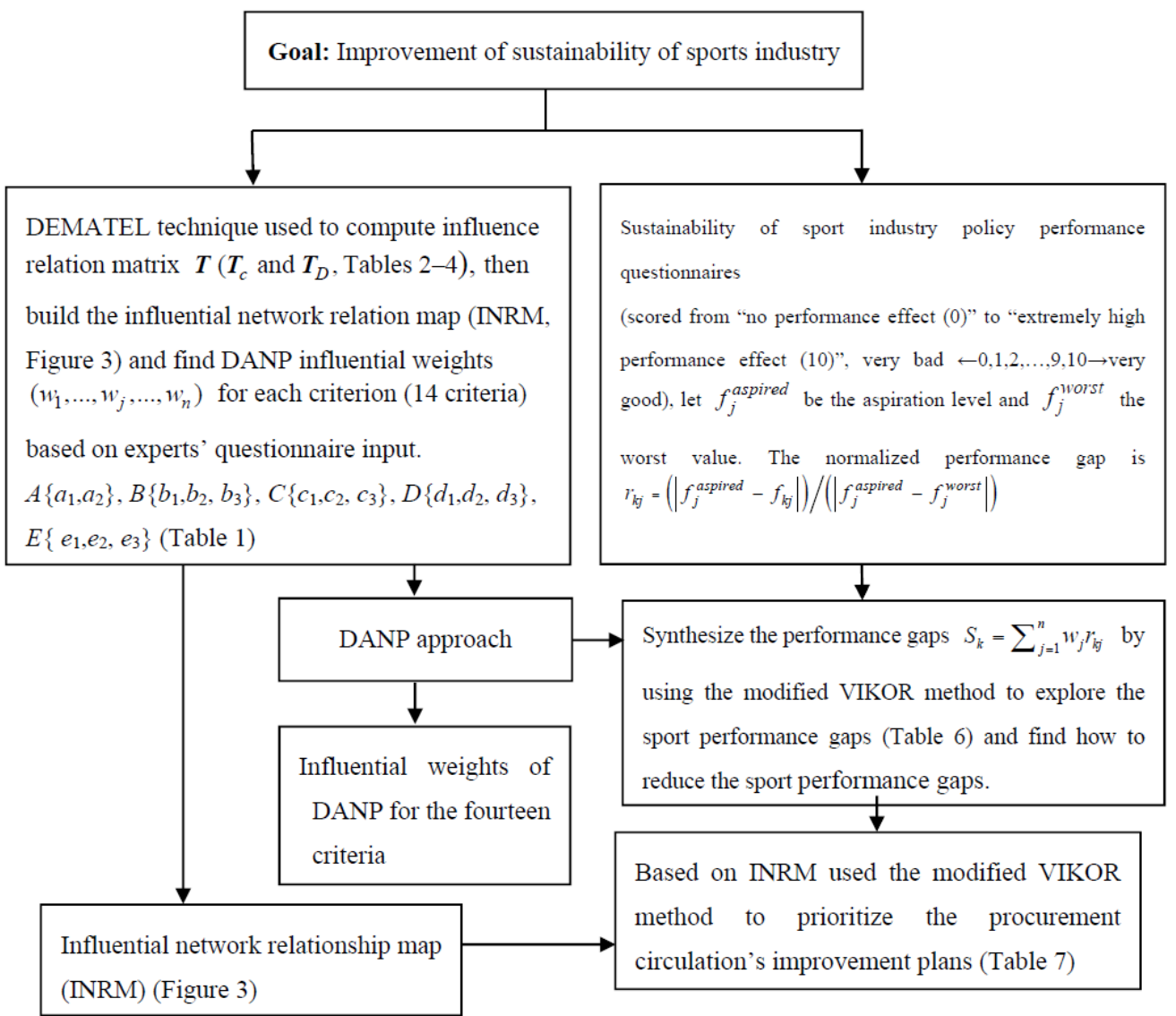

Figure 2. Diagram of the process for the empirical case. 


\subsection{Background and Problem Statements}

The promotion of sustainability of sports industry policy not only improves the level of domestic sports, but also creates investment and employment opportunities that stimulate the country's economic development. However, the devotion of manpower and material resources is indispensable to the development of the industry as well as support through cultural and social recognition. Based on the School Sports Statistics Annual Report annually published by Taiwan's Department of Education, Hsu et al. (2013) [61] suggested the development of a school sports database and construction of a national unit responsible for sports statistics as a means to effectively increase research efforts and international exposure to sports activities. Yeh (2010) [72] pointed out that although some sports industry policies in fact contribute to sustainable development in Taiwan, there is still room for improvement compared to countries with an advanced sports policy. At present, Taiwan's authorities are sparing no efforts to promote the sports industry. However, the distribution of resources is not flawless and resources are limited. In order to enhance the quality of sustainability of Taiwan's sports industry policy and national competitiveness, the orderly implementation of a comprehensive sports development plan is the priority. The amendment to the "Sports Industry Development Act" in July 2011 was intended to build a high-quality sports and recreational environment for the people and to enhance Taiwan's competitiveness so as to converge with the rest of the world [28]. In this study, based on the above background and problem statements, the authors use a new decision model as an empirical example for how to plan to improve sustainability of Taiwan's sport industry policies.

\subsection{Operations and Results}

The DEMATEL technique is employed to construct an INRM that illustrates the multiple network relationship between the criteria related to improvement of sustainability of the nation's sports industry policy. The average initial direct-influence $5 \times 5$ matrix $D$ is obtained through pair-wise comparison to indicate the direction of influence of dimensions on one another, and the normalized direct-influence matrix $X$ is calculated using Equations (2) and (3), the total-influence matrix $T_{D}$ of the dimensions, and the sum of the total influence given and received by each dimension using Equation (4), as indicated in Table 2. Table 2 and Figure 3 show the network relationship between the total influence-relation matrix and the perspectives to identify the inter-relationships between all perspectives. Here, $d_{i}+r_{i}$ and $d_{i}-r_{i}$ represent the degree of relationship between the dimensions and the effect of one dimension on the others, respectively, which can be derived and the results shown in Tables 2 and 4 using Equations (5) and (6). The higher the value of $d_{i}+r_{i}$ is, the stronger the relationships are with other perspectives, and vice versa.

Table 2. Total influence matrix $T$ : five perspectives.

\begin{tabular}{cccccccccc}
\hline Perspectives & $\boldsymbol{A}$ & $\boldsymbol{B}$ & $\boldsymbol{C}$ & $\boldsymbol{D}$ & $\boldsymbol{E}$ & $\begin{array}{c}\text { Row } \\
\text { Sum }\left(\boldsymbol{d}_{\boldsymbol{i}}\right)\end{array}$ & $\begin{array}{c}\text { Column } \\
\text { Sum }\left(\boldsymbol{r}_{\boldsymbol{i}}\right)\end{array}$ & $\boldsymbol{d}_{\boldsymbol{i}}+\boldsymbol{r}_{\boldsymbol{i}}$ & $\boldsymbol{d}_{\boldsymbol{i}}-\boldsymbol{r}_{\boldsymbol{i}}$ \\
\hline$A$ & 0.587 & 0.623 & 0.694 & 0.623 & 0.621 & 3.149 & 3.016 & 6.164 & $0.133(1)$ \\
$B$ & 0.584 & 0.569 & 0.649 & 0.585 & 0.574 & 2.961 & 3.040 & 6.001 & $-0.079(4)$ \\
$C$ & 0.637 & 0.640 & 0.688 & 0.637 & 0.637 & 3.240 & 3.385 & 6.625 & $-0.146(5)$ \\
$D$ & 0.612 & 0.611 & 0.686 & 0.597 & 0.606 & 3.113 & 3.037 & 6.150 & $0.077(2)$ \\
$E$ & 0.596 & 0.597 & 0.668 & 0.594 & 0.576 & 3.030 & 3.015 & 6.046 & $0.015(3)$ \\
\hline
\end{tabular}




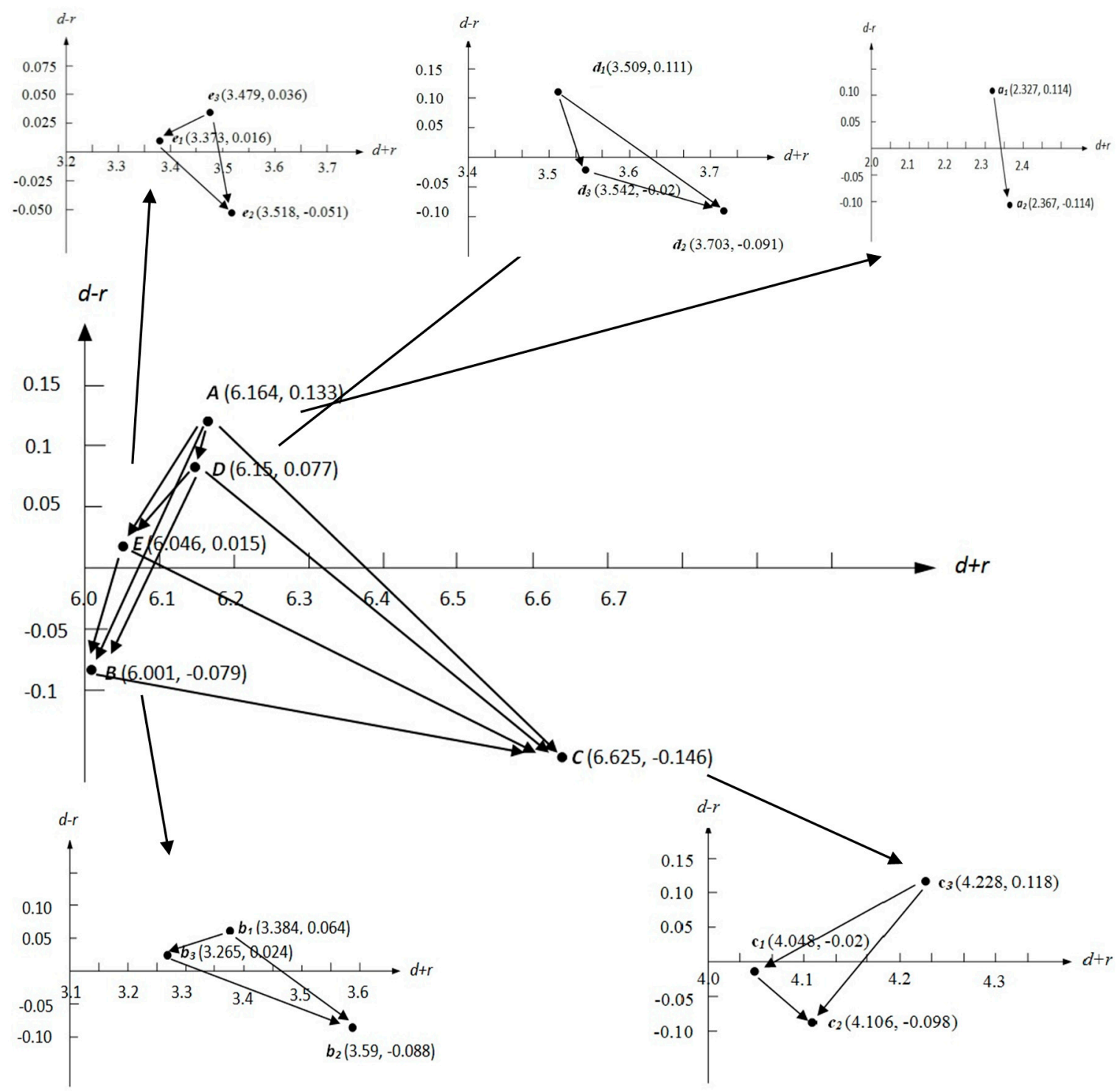

Figure 3. The INRM of total influence relationships for sustainability of sports industry policy.

Table 2 shows that the perspective of sports competitions and events $(C)$ is the factor that has the most strength of influences given and received (is 6.625), followed by promotion and assistance of government policy (A), sports venues and facilities (D), and enterprise sponsorships of sports (E), respectively. The perspective of expert human resources (B) has the least strength of influences given and received (is 6.001). In other words, sports competitions and events (C) form the most influential perspective. Moreover, if is positive, then it means that this perspective has an effect on the other perspectives, implying that it should have a high priority for improvement. Promotion and assistance of government policy (A) show the strongest influence on the other perspectives (highest value), while the perspective of sports competitions and events is the most sensitive (lowest with a negative value).

Promotion and assistance of government policy (A) should therefore be given the top priority for improvement, because this perspective influences the other perspectives. The optimal strategy for promoting sustainability of the sports policy is to strengthen promotion and assistance through government policy. The total influence-relation matrix $T$ in Table 3 shows that all criteria are inter-dependent (group consensuses with the consensus value gap being 0.85\% (less than 1\%); significance at the confidence level of $99.15 \%$, which is more than $99 \%$ ). 
Table 3. Total influence-relation matrix $T$ : fourteen criteria.

\begin{tabular}{ccccccccccccccc}
\hline Criteria & $\boldsymbol{a}_{1}$ & $\boldsymbol{a}_{2}$ & $\boldsymbol{b}_{1}$ & $\boldsymbol{b}_{2}$ & $\boldsymbol{b}_{3}$ & $\boldsymbol{c}_{1}$ & $\boldsymbol{c}_{2}$ & $\boldsymbol{c}_{3}$ & $\boldsymbol{d}_{1}$ & $\boldsymbol{d}_{2}$ & $\boldsymbol{d}_{3}$ & $\boldsymbol{e}_{1}$ & $\boldsymbol{e}_{2}$ & $\boldsymbol{e}_{3}$ \\
\hline$a_{1}$ & 0.546 & 0.674 & 0.634 & 0.687 & 0.624 & 0.699 & 0.723 & 0.714 & 0.610 & 0.676 & 0.660 & 0.627 & 0.664 & 0.649 \\
$a_{2}$ & 0.560 & 0.567 & 0.578 & 0.649 & 0.568 & 0.658 & 0.699 & 0.673 & 0.569 & 0.630 & 0.595 & 0.577 & 0.615 & 0.596 \\
$b_{1}$ & 0.559 & 0.608 & 0.515 & 0.647 & 0.562 & 0.649 & 0.669 & 0.650 & 0.554 & 0.626 & 0.582 & 0.555 & 0.592 & 0.575 \\
$b_{2}$ & 0.565 & 0.640 & 0.597 & 0.578 & 0.576 & 0.659 & 0.682 & 0.666 & 0.566 & 0.639 & 0.593 & 0.570 & 0.604 & 0.584 \\
$b_{3}$ & 0.544 & 0.587 & 0.548 & 0.614 & 0.483 & 0.613 & 0.629 & 0.622 & 0.541 & 0.603 & 0.565 & 0.545 & 0.580 & 0.564 \\
$c_{1}$ & 0.582 & 0.647 & 0.611 & 0.673 & 0.582 & 0.613 & 0.708 & 0.693 & 0.596 & 0.662 & 0.621 & 0.598 & 0.644 & 0.618 \\
$c_{2}$ & 0.583 & 0.668 & 0.612 & 0.673 & 0.585 & 0.682 & 0.632 & 0.690 & 0.535 & 0.663 & 0.624 & 0.604 & 0.647 & 0.619 \\
$c_{3}$ & 0.637 & 0.706 & 0.663 & 0.726 & 0.637 & 0.739 & 0.763 & 0.672 & 0.643 & 0.715 & 0.671 & 0.645 & 0.693 & 0.670 \\
$d_{1}$ & 0.585 & 0.654 & 0.604 & 0.661 & 0.584 & 0.689 & 0.708 & 0.696 & 0.525 & 0.664 & 0.621 & 0.590 & 0.631 & 0.609 \\
$d_{2}$ & 0.583 & 0.653 & 0.606 & 0.661 & 0.589 & 0.681 & 0.706 & 0.690 & 0.597 & 0.588 & 0.621 & 0.591 & 0.631 & 0.608 \\
$d_{3}$ & 0.575 & 0.622 & 0.585 & 0.640 & 0.570 & 0.660 & 0.680 & 0.667 & 0.578 & 0.644 & 0.539 & 0.579 & 0.617 & 0.598 \\
$e_{1}$ & 0.551 & 0.619 & 0.569 & 0.623 & 0.555 & 0.642 & 0.662 & 0.649 & 0.549 & 0.604 & 0.579 & 0.503 & 0.604 & 0.586 \\
$e_{2}$ & 0.561 & 0.632 & 0.586 & 0.640 & 0.569 & 0.669 & 0.690 & 0.672 & 0.568 & 0.632 & 0.597 & 0.585 & 0.554 & 0.595 \\
$e_{3}$ & 0.570 & 0.642 & 0.586 & 0.652 & 0.588 & 0.667 & 0.686 & 0.677 & 0.571 & 0.636 & 0.607 & 0.590 & 0.627 & 0.540 \\
\hline \multicolumn{7}{c}{ Average gaps $=\frac{1}{n(n-1)} \sum_{i} \sum$} \\
\multicolumn{7}{c}{$\left(\frac{\left|\bar{a}_{i j}^{20}-\bar{a}_{i j}^{19}\right|}{\bar{a}_{i j}^{20}}\right) \times 100 \%=0.85 \%<1 \% ; a_{i j}^{19}$ and $a_{i j}^{20}$ denote the average scores of the }
\end{tabular}

Table 4 shows the influential network relationship of all criteria. The most important criterion to be considered in the sports policy formulation is the promotion of professional sports games $\left(c_{3}\right)$ (highest $d_{i}+r_{i}$ value), while the provision of counseling and incentives $\left(a_{1}\right)$ has the least influence on the other criteria. Similarly, the promotion of professional sports games $\left(c_{3}\right)$ has the highest $d_{i}-r_{i}$ value, meaning it has the greatest direct influence on the other criteria. However, the promotion of international sports exchanges $\left(a_{2}\right)$ is the most likely to be influenced by the other criteria (lowest $d_{i}-r_{i}$ value). This implies that the promotion of professional sports games $\left(c_{3}\right)$ should be first improved, because it can influence the other criteria. There are also significant causal relationships between the five perspectives. Among those, the $d_{i}-r_{i}$ values of A (Promotion and assistance of government policy), D (Sports venues and facilities), and E (Enterprise sponsorship of sports) are all positive, showing that these dimensions affect the other dimensions. By contrast, B (Expert human resources) and C (Sports competitions and events) have negative $d_{i}-r_{i}$ values, suggesting they are actually affected by the other dimensions. Based on these findings, decision-makers will be able to ascertain the priority for improvement from the complex criteria.

By adopting the influence-relation matrix of DEMATEL and using the basic concept of ANP, the DANP influential weights can be obtained and the dynamic relationship among the criteria can be established. DANP is employed to obtain the influential weight for each criterion to construct an evaluation model for the sports policy. The DEMATEL-based un-weighted super-matrix $\left(\boldsymbol{W}=\left(\boldsymbol{T}_{c}^{\alpha}\right)^{\prime}\right)$ is obtained by making pairwise comparisons between the criteria using Equations (10)-(12). The weighted super-matrix is created from $W^{\alpha}=T_{D}^{\alpha} W$ using Equations (13) and (14). The limiting power of the weighted super-matrix $\left(\lim _{g \rightarrow \infty}\left(W^{\alpha}\right)^{g}\right)$ is used to achieve long-term stability. Each row sets forth the influential weights of DANP for each criterion (global weights), as shown in Table 5 . Finally, the performance gaps are obtained using the modified VIKOR method by combining the influential weights that can be integrated with the performance gaps from each criterion for the perspectives/dimensions and overall performance.

The purpose of this study is to propose the most suitable improvement strategy for sustainable development of Taiwan's sports industry policy. The modified VIKOR method is employed to evaluate the overall performance gaps (or called regret) of sustainable development for the national sports industry policy. The score of each criterion and the total average gap $\left(S_{k}=L_{k}^{p=1}=\sum_{j=1}^{n} w_{j} r_{k j}\right)$ in Taiwan's sports industry policy are acquired by taking the global weights from the DANP influential weights in order to be multiplied with the gap $\left(r_{k j}\right)$. The average performance value can be obtained from the performance values $\left(f_{k j} \mid j=1,2, \ldots, n\right)$ and relative gaps 
$\left(r_{k j}=\left(\left|f_{j}^{\text {aspired }}-f_{k j}\right|\right) /\left(\left|f_{j}^{\text {aspired }}-f_{j}^{\text {worst }}\right|\right) \mid j=1,2, \ldots, n\right)$ of all criteria as illustrated in Table 6 . With the help of these performance values, decision-makers will be able to find solutions for all sorts of problems, for each perspective, or for the perspective of the criteria as a whole.

Table 4. The sum of the influences given and received on the perspectives and criteria.

\begin{tabular}{ccccc}
\hline Perspectives/Criteria & Row Sum $\left(d_{i}\right)$ & Column Sum $\left(r_{i}\right)$ & $d_{i}+r_{i}$ & $d_{i}-r_{i}$ \\
\hline Promotion and assistance of government policy $(A)$ & 3.149 & 3.016 & $\mathbf{6 . 1 6 4}$ & $\mathbf{0 . 1 3 3}$ \\
\hline $\begin{array}{c}\text { Provision of counseling and incentives for all sports } \\
\text { industries }\left(a_{1}\right)\end{array}$ & 1.220 & 1.107 & 2.327 & 0.114 \\
\hline Promotion of international sports exchanges $\left(a_{2}\right)$ & 1.127 & 1.240 & 2.367 & -0.114 \\
\hline Expert human resources $(B)$ & $\mathbf{2 . 9 6 1}$ & $\mathbf{3 . 0 4 0}$ & $\mathbf{6 . 0 0 1}$ & $-\mathbf{0 . 0 7 9}$ \\
\hline $\begin{array}{c}\text { Establishment of professional certification management } \\
\text { system by government }\left(b_{1}\right)\end{array}$ & 1.724 & 1.660 & 3.384 & 0.064 \\
\hline Training of expert human resources $\left(b_{2}\right)$ & 1.751 & 1.839 & 3.590 & -0.088 \\
\hline Formation of industry-academic cooperation $\left(b_{3}\right)$ & 1.644 & 1.620 & 3.265 & 0.024 \\
\hline Sports competitions and events $(C)$ & 3.240 & 3.385 & $\mathbf{6 . 6 2 5}$ & $-\mathbf{0 . 1 4 6}$ \\
\hline Organizing and holding national sports events $\left(c_{1}\right)$ & 2.014 & 2.034 & 4.048 & -0.020 \\
\hline Organizing and holding international sports events $\left(c_{2}\right)$ & 2.004 & 2.102 & 4.106 & -0.098 \\
\hline Promotion of professional sports games $\left(c_{3}\right)$ & 2.173 & 2.055 & 4.228 & 0.118 \\
\hline Sports venues and facilities $(D)$ & 3.113 & 3.037 & $\mathbf{6 . 1 5 0}$ & $\mathbf{0 . 0 7 7}$ \\
\hline Widespread public sports venues and facilities $\left(d_{1}\right)$ & 1.810 & 1.699 & 3.509 & 0.111 \\
\hline Operating and management of public sports venues $\left(d_{2}\right)$ & 1.806 & 1.897 & 3.703 & -0.091 \\
\hline Government incentives for the private sector to invest, & 1.761 & 1.781 & 3.542 & -0.020 \\
\hline build or operate sports venues $\left(d_{3}\right)$ & 3.030 & 3.015 & $\mathbf{6 . 0 4 6}$ & $\mathbf{0 . 0 1 5}$ \\
\hline Enterprise sponsorship of sports $(E)$ & 1.694 & 1.679 & 3.373 & 0.016 \\
\hline Sponsorship of sports groups $\left(e_{1}\right)$ & 1.733 & 1.785 & 3.518 & -0.051 \\
\hline Sponsorship of sports events $\left(e_{2}\right)$ & 1.757 & 1.721 & 3.479 & 0.036 \\
\hline Sponsorship of sports teams $\left(e_{3}\right)$ & &
\end{tabular}

Table 5. Influential weights of DANP for each criterion obtained by $\lim _{g \rightarrow \infty}\left(W^{\alpha}\right)^{g}$.

\begin{tabular}{ccccccccccccccc}
\hline Criteria & $\boldsymbol{a}_{1}$ & $\boldsymbol{a}_{2}$ & $\boldsymbol{b}_{1}$ & $\boldsymbol{b}_{2}$ & $\boldsymbol{b}_{3}$ & $\boldsymbol{c}_{1}$ & $\boldsymbol{c}_{2}$ & $\boldsymbol{c}_{3}$ & $\boldsymbol{d}_{1}$ & $\boldsymbol{d}_{2}$ & $\boldsymbol{d}_{3}$ & $\boldsymbol{e}_{1}$ & $\boldsymbol{e}_{2}$ & $\boldsymbol{e}_{3}$ \\
\hline $\begin{array}{l}\text { Weights } \\
\text { (DANP) }\end{array}$ & 0.066 & 0.073 & 0.068 & 0.075 & 0.066 & 0.076 & 0.079 & 0.077 & 0.066 & 0.073 & 0.070 & 0.067 & 0.071 & 0.069 \\
\hline
\end{tabular}

As shown in Table 6, in order to achieve the aspiration level, the performance values and the gap values of the 14 criteria are listed. This helps establish the size of the gap for improvement. Of the five dimensions, sports competitions and events $(C)$ has the lowest performance value (6.607) and the highest gap (0.339). It has the largest gap to achieve the targeted goal. On the other hand, sports venues and facilities (D) has the highest performance value (7.162) and the lowest gap (0.284). Decision-makers can set an aspiration level (the goal is 10 as the aspiration level) as a strategic objective. In addition, the average performance value is 6.943 and the average gap is 0.302 , indicating that the distance from the optimal level exceeds $30.2 \%$. There is clearly room for improvement in the government's promotion of sustainability of its sports industry policy. 
Table 6. Integrated index of sustainability of sports industry policy dimensions and criteria.

\begin{tabular}{|c|c|c|c|c|}
\hline & Local Weights & Global Weights & Performance & Relative Gaps $\left(r_{k j}\right)$ \\
\hline $\begin{array}{l}\text { Promotion and assistance of } \\
\text { government policy }(A)\end{array}$ & 0.139 & - & $7.150(2)$ & $0.285(4)$ \\
\hline $\begin{array}{l}\text { Provision of counseling and incentives } \\
\text { for all sports industries }\left(a_{1}\right)\end{array}$ & 0.474 & 0.066 & 7.647 & 0.235 \\
\hline $\begin{array}{l}\text { Promotion of international sports } \\
\text { exchanges }\left(a_{2}\right)\end{array}$ & 0.526 & 0.073 & 6.706 & 0.329 \\
\hline Expert human resources $(B)$ & 0.209 & - & $6.953(4)$ & $0.305(2)$ \\
\hline $\begin{array}{c}\text { Establishment of a professional } \\
\text { certification management system by } \\
\text { government }\left(b_{1}\right)\end{array}$ & 0.326 & 0.068 & 6.765 & 0.324 \\
\hline $\begin{array}{l}\text { Training of expert human resources } \\
\qquad\left(b_{2}\right)\end{array}$ & 0.358 & 0.075 & 6.824 & 0.318 \\
\hline $\begin{array}{l}\text { Formation of industry-academic } \\
\text { cooperation }\left(b_{3}\right)\end{array}$ & 0.317 & 0.066 & 7.294 & 0.271 \\
\hline Sports competitions and events $(C)$ & 0.233 & - & $6.607(5)$ & $0.339(1)$ \\
\hline $\begin{array}{l}\text { Organizing and holding national } \\
\text { sports events }\left(c_{1}\right)\end{array}$ & 0.328 & 0.076 & 6.176 & 0.382 \\
\hline $\begin{array}{l}\text { Organizing and holding international } \\
\text { sports events }\left(c_{2}\right)\end{array}$ & 0.340 & 0.079 & 6.294 & 0.371 \\
\hline $\begin{array}{l}\text { Promotion of professional sports } \\
\text { games }\left(c_{3}\right)\end{array}$ & 0.332 & 0.077 & 7.353 & 0.265 \\
\hline Sports venues and facilities $(D)$ & 0.209 & - & $7.162(1)$ & $0.284(5)$ \\
\hline $\begin{array}{l}\text { Widespread public sports venues and } \\
\text { facilities }\left(d_{1}\right)\end{array}$ & 0.317 & 0.066 & 7.118 & 0.288 \\
\hline $\begin{array}{l}\text { Operating and management of public } \\
\text { sports venues }\left(d_{2}\right)\end{array}$ & 0.349 & 0.073 & 7.412 & 0.259 \\
\hline $\begin{array}{c}\text { Government incentives for the private } \\
\text { sector to invest, build or operate } \\
\text { sports venues }\left(d_{3}\right)\end{array}$ & 0.333 & 0.070 & 6.941 & 0.306 \\
\hline Enterprise sponsorship of sports $(E)$ & 0.207 & - & $7.058(3)$ & $0.294(3)$ \\
\hline Sponsorship of sports groups $\left(e_{1}\right)$ & 0.323 & 0.067 & 7.059 & 0.294 \\
\hline Sponsorship of sports events $\left(e_{2}\right)$ & 0.344 & 0.071 & 7.000 & 0.300 \\
\hline Sponsorship of sports teams $\left(e_{3}\right)$ & 0.333 & 0.069 & 7.118 & 0.288 \\
\hline Total performances & - & - & 6.943 & - \\
\hline Total gap $\left(S_{k}\right)$ & - & - & - & 0.302 \\
\hline
\end{tabular}

\section{Discussion and Implications}

Figure 1 shows the perspectives and criteria measured in this study for the promotion of sustainability of Taiwan's sports industry policy illustrated by INRM. Based on the degree of the effect, improvement should be made according to the following order: promotion and assistance of government policy, sports venues and facilities, enterprise sponsorships in sports, sports competitions and events, and expert human resources. All participating professionals held the same view, that more efforts should be devoted to promotion and assistance of government policy, because this perspective has immediate network effects on the other perspectives and can help resolve multiple problems at the same time. Within an individual dimension, the influence network relationship of certain criteria also has the same effects. These are the provisions of counseling and incentives for all sports industries $\left(a_{1}\right)$, establishment of a professional certification management system by government $\left(b_{1}\right)$, promotion of professional sports games $\left(c_{3}\right)$, widespread public sports venues and facilities $\left(d_{1}\right)$ and enterprise sponsorship of sports teams $\left(e_{3}\right)$. These are the major influential factors within each perspective. 
The findings imply that the government should strengthen its provision of counseling and incentives for sports industry policies, such as providing counseling and subsidies for the National Intercollegiate Athletic Games, sports events, and sports training, as well as subsidies for scholars to attend international conferences for the academic study of sports. The establishment of a professional certificate management by the government will help enhance the value of sports professionals, which will in turn improve the expertise of human resources. The promotion of professional sports games is the most important part of sports competitions and such events will facilitate Taiwan's economic sustainable development. Establishing safe and practical public sports venues and facilities will bring about the desired effect and allow the functions of sports venues to expand and further facilitate the sustainable development of the sports industry. Finally, enterprises' support of the sports industry, in the form of sponsoring sports teams and providing resources for training and competition, will increase athletes' participation and enthusiasm. Decision-makers can consider the relationship between multiple solutions and formulate the proper direction for improvement (Table 5).

As can be seen in Table 6, the average performance value of sustainability of the sports industry policy is 6.943 (the aspiration level is 10) and the average gap for improvement is 0.302 (the maximum gap value is 1). Among the five major perspectives, sports competitions and events have the largest gap (0.339). This means that if the government intends to promote the sustainable development of the sports industry policy in Taiwan, improvement of this dimension has to be exerted to achieve the aspired level. According to the Sports Administration Department, Ministry of Education, Taiwan, up to fifty items of international sport events were held in Taiwan in 2014. Perhaps international visibility is not enough, and so it is unable to impel sports industry sustainable development. In addition, the scale of professional sports in Taiwan is very small, with professional baseball and basketball lacking smooth development. Perhaps cross-strait professional sports can be combined to expand the market scale and attract wider audience interest.

Among the 14 criteria (Table 6), the organizing and holding of national sports events for all sports industry policy have the largest gap value, showing they have the greatest room for improvement. Although large-scale sports events, such as the Taiwan Regional Games, the National Intercollegiate Athletic Games, and the Taiwan National High School Games, are held in Taiwan regularly, they have failed to achieve the desired effect of promoting sustainability of Taiwan's sports industry. However, from the definition of the sustainability of sports industry policy in this study, we know there are few professional basketball teams and professional baseball teams in Taiwan and there is a lack of enterprise sponsorships of sports, etc. Thus, there are not enough resources to support the long-term development of the national sports industry. The national sports industry policy can lay the foundation for Taiwan's sports industry. In recent years, efforts have been made to offer proper counseling and incentives to stimulate activities related to the sports industry through the promulgation of the Sports Industry Development Act. This has further strengthened the sustainable development of Taiwan's sports industry policy.

In order to promote a national sports culture and rejuvenate sustainability of Taiwan's sports industry, SAC proposed "the Improvement of National Sports Environment and Sports Island Establishment Project", which was intended to plan a sound sports environment and offer better sports resources for the purpose of promoting sustainability of the sports industry policy throughout Taiwan. Since sustainability of the sports industry policy covers a wide range of scope, it is clear from the promotion and implementation of the Sports Industry Development Act that authorities want to strengthen all aspects of the sports industry. However, due to limited resources, it has proven impractical to implement all plans at the same time. The analytical results in Table 7 can serve as a reference for the responsible authorities to determine priorities for improvement, leading to more effective development. 
Table 7. The sports industry policy sustainable development implementation and improvement plan.

\begin{tabular}{cc}
\hline Formula & Order of Improvement \\
\hline F1: Influential network relationship of DEMATEL dimensions & $A_{-} D_{-} E_{-} B_{-} C$ \\
& $A_{\left(a_{1}\right)_{-}\left(a_{2}\right)}$ \\
F2: Influential network relationship of the criteria within a dimension & $B:\left(b_{1}\right)_{-}\left(b_{3}\right)_{-}\left(b_{2}\right)$ \\
& $C_{\left(c_{3}\right)_{-}\left(c_{1}\right)_{-}\left(c_{2}\right)}$ \\
& $E:\left(d_{1}\right)_{-}\left(d_{3}\right)_{-}\left(d_{2}\right)$ \\
& $E:\left(e_{3}\right)_{-}\left(e_{1}\right)_{-}\left(e_{2}\right)$ \\
\hline
\end{tabular}

\section{Conclusions}

This research proposes an improvement strategy for sustainability of Taiwan's sports industry policy, which may serve as reference for the government to evaluate this industry's sustainable development and to promote national sports participation sustainability. A new hybrid model is constructed by integrating the DEMATEL, DANP, and modified VIKOR methods to illustrate the inter-relationship between the influential factors. Here, DEMATEL is mainly used to construct INRM and the weighted super-matrix, DANP is used to resolve the inter-dependency and feedback relationship, and the modified VIKOR method is employed to integrate the performance gaps of each criterion within each dimension and overall. Based on the degree of the effect, consideration should be given as follows: promotion and assistance of government policy, sports venues and facilities, enterprise sponsorship of sports, expert human resources, sports competitions and events. The results of the performance evaluation show that the average gap is 0.302 , which indicates that there is still room for improvement in the sustainable development of Taiwan's sports industry policy. The datasets used in this research were tested by the consensus of experts. The research methodology discussed herein is capable of dealing with complex issues related to the sustainable development of the sports industry policy. Not only does this research have profound implications for the responsible authorities, but, even more importantly, it also proposes a feasible and adequate development strategy for sustainability the sports industry policy, which can assist the government in its improvement of the quality of the sports industry policy and increase the goals of national participation sports.

Several limitations of this study remain, which require further examination. First, a review of the literature for the choice evaluation criteria should be made and longitudinal studies should be applied by authorities to identify other possible criteria. Although this paper establishes a new decision model to improve the effectiveness of the current sports industry policy, some issues may be worth investigating in future. Second, this study developed an evaluation model that helps decision-makers understand the critical criteria when evaluating the implementation of plans for improving sustainability of sports industry policy. Future studies can adopt additional multi-criteria approaches to estimate the relative weight of the influence on sustainability of sport industry policy implementation. The results of future studies can then be compared with those presented here.

Author Contributions: Kuang-Hua $\mathrm{Hu}$ and Fu-Hsiang Chen drafted the manuscript. Kuang-Hua Hu and Gwo-Hshiung Tzeng participated in the design of the study and performed the statistical analysis. Fu-Hsiang Chen coordination and helped to draft the manuscript. All authors read and approved the final manuscript.

Conflicts of Interest: The authors declare no conflict of interest.

\section{References}

1. Beyers, W.B. Culture, services and regional development. Serv. Ind. J. 2002, 22, 4-34. [CrossRef]

2. Cornelissen, S. More than a sporting chance? Appraising the sport for development legacy of the 2010 FIFA World Cup. Third World Q. 2011, 32, 503-529. [CrossRef]

3. Hsiao, C.T.; Peng, H.L.; Huang, H.H. The impact of sports ethics of professional baseball player to the development of sports industry in Taiwan. Qual. Quant. 2012, 46, 1753-1767. [CrossRef] 
4. Skinner, J.; Zakus, D.H. Development through sport: Building social capital in disadvantaged communities. Sport Manag. Rev. 2008, 11, 253-275. [CrossRef]

5. WHO. Move for Health. 2002. Available online: http://www.who.int/world-health-day/previous/2002/ en/ (accessed on 26 March 2015).

6. United Nations General Assembly. Sport as a Means to Promote Education, Health, Development and Peace (3 November 2003); United Nations General Assembly: New York, NY, USA, 2003; Available online: http://www.un.org/en/ga/search/view_doc.asp?symbol=A/RES/58/5 (accessed on 10 July 2015).

7. De Bosscher, V.; Shibli, S.; Bottenburg, M.; Knop, P.D.; Truyens, J. Developing a method for comparing the elite sport systems and policies of nations: A mixed research methods approach. J. Sport Manag. 2010, 24, 567-600.

8. Vuori, I.; Paronen, O.; Oja, P. How to develop local physical activity promotion programmes with national support: The Finnish experience. Patient Educ. Couns. 1998, 33, S111-S120. [CrossRef]

9. Shilbury, D.; Sotiriadou, K.; Green, B.C. Sport development. Systems, policies and pathways: An introduction to the special issue. Sport Manag. Rev. 2008, 11, 217-223. [CrossRef]

10. Green, M.; Collins, S. Policy, politics and path dependency: Sport development in Australia and Finland. Sport Manag. Rev. 2008, 11, 225-251. [CrossRef]

11. Bloomfield, J. The Contribution of sports science and sports medicine to the development of the Australian sports. J. Sci. Med. Sport 2002, 5, 1-8. [CrossRef]

12. Hill, J. From "Rational Recreation" to "Sport for All": The place of the municipality in sport and leisure. In Sport, Leisure and Culture in Twentieth-Century Britain; Palgrave Macmillan: Basingstoke, UK, 2002; pp. 165-178.

13. Trimble, L. Part one the strategic direction of UK sport. In Sport in the UK; Learning Matters: Nashville, TN, USA, 2010; pp. 1-16.

14. Sport England. The English Sports Council Grant-in-aid and National Lottery Distribution Fund Annual Report and Financial Statement 2011-2012. 2012. Available online: http://www.sportengland.org/media/ 187740/2012--13-sport-england-annual-report-and-accounts.pdf (accessed on 16 May 2015).

15. Hunt, T.M. American sport policy and the cultural cold war: The Lyndon B. Johnson presidential years. J. Sport Hist. 2006, 33, 273-297.

16. Deutscher Sportbund. Sport in Deutschland. 2003. Available online: https://www.dosb.de/fileadmin/fmdsb/arbeitsfelder/wiss-ges/Dateien/Sport_in_Deutschland.pdf (accessed on 27 June 2016).

17. Houlihan, B. Public sector sport policy developing a framework for analysis. Int. Rev. Soc. Sport 2005, 40, 163-185. [CrossRef]

18. Wicker, P.; Prinz, J.; Von Hanau, T. Estimating the value of national sporting success. Sport Manag. Rev. 2012, 15, 200-210. [CrossRef]

19. Liu, C.H.; Tzeng, G.H.; Lee, M.H. Strategies for improving cruise product sales using hybrid 'multiple criteria decision making' models. Serv. Ind. J. 2013, 33, 542-563. [CrossRef]

20. Hsu, C.W.; Kuo, T.C.; Shyu, G.S.; Chen, P.S. Low carbon supplier selection in the hotel industry. Sustainability 2014, 6, 2658-2684. [CrossRef]

21. Chang, D.S.; Chen, S.H.; Hsu, C.W.; Hu, A.H.; Tzeng, G.H. Evaluation framework for alternative fuel vehicles: Sustainable development perspective. Sustainability 2015, 7, 11570-11594. [CrossRef]

22. Babashamsi, P.; Md Yusoff, N.I.; Ceylan, H.; Md Nor, N.G.; Salarzadeh Jenatabadi, H. Sustainable development factors in pavement life-cycle: Highway/Airport review. Sustainability 2016, 8, 248. [CrossRef]

23. Hwang, B.N.; Huang, C.Y.; Wu, C.H. A TOE approach to establish a green supply chain adoption decision model in the semiconductor industry. Sustainability 2016, 8, 168. [CrossRef]

24. Van Tuyckom, C.; Jöreskog, K.G. Going for gold! Welfare characteristics and Olympic success: An application of the structural equation approach. Qual. Quant. 2012, 46, 189-205. [CrossRef]

25. Yuen, B. Sport and urban development in Singapore. Cities 2008, 25, 29-36. [CrossRef]

26. Keat, R.A.; Sam, M.P. Regional implementation of New Zealand sport policy: New instrument, new challenges. Int. J. Sport Policy Politics 2013, 5, 39-54. [CrossRef]

27. De Bosscher, V.; De Knop, P.; van Bottenberg, M.; Shibli, S. A conceptual framework for analysing sports policy factors leading to international sporting success. Eur. Sport Manag. Q. 2006, 6, 185-215. [CrossRef]

28. SAC. Sports Industry Development Act. Available online: http://edu.law.moe.gov.tw/EngLawContent. aspx? Type $=E \& i d=91.2011$ (accessed on 10 January 2015). 
29. Huish, R.; Darnell, S.C. Solidarity, counter-hegemony, and development: Exploring new dimensions of Cuba's sport-based internationalism. Can. J. Lat. Am. Caribb. Stud. 2011, 36, 139-164. [CrossRef]

30. Wolsey, C.; Minten, S.; Abrams, J. Human Resource Management in the Sport and Leisure Industry; Routledge: Abingdon, UK, 2012.

31. Feng, B. Study on development path of shandong sports industry from the perspective of low-carbon economy. Energy Procedia 2011, 5, 879-883.

32. Ghasemzadeh Mirkolaee, E.; Razavi, S.M.H.; Amirnejad, S. A mini-review of track and field's talent-identification models in Iran and some designated countries. Ann. Appl. Sport Sci. 2013, 1, 17-28.

33. Sujiao, Z. Research on sustainable development of college sport education. In Information and Business Intelligence; Springer: Berlin, Germany; Heidelberg, Germany, 2012; pp. 484-489.

34. Irwin, C.; Irwin, R.; Richey, P.; Miller, M.; Boddie, J.; Dickerson, T. Get fit with the Grizzlies: A community-school-home initiative to fight childhood obesity led by a professional sports organization. Stud. Health Technol. Inform. 2012, 172, 163-167. [PubMed]

35. Paci, R.; Marrocu, E. Knowledge assets and regional performance. Growth Chang. 2013, 44, $228-257$. [CrossRef]

36. Mwisukha, A. Evaluation of the professional preparation and certification of athletics coaches in Kenya. In Proceedings of the Joint Congress 2007 SEA games and ASEAN Para Games Scientific Congress and 5th Bangkok ASPASP International Congress on Sport Psychology, Bangkok, Thailand, 1-4 December 2007.

37. Welty Peachey, J.; Cunningham, G.; Lyras, A.; Cohen, A.; Bruening, J. Exploring participant motivations to take part in an elite, multinational, sport-for-development event. Event Manag. 2014, 18, 153-168. [CrossRef]

38. Sport England. Annual Report and Financial Statements 2013-14. 2014. Available online: http://www. sportengland.org/media/339673/annual-report-2013--14.pdf (accessed on 18 March 2015).

39. Hiller, H. Mega-events, urban boosterism and growth strategies: An analysis of the objectives and legitimations of the Cape Town 2004 Olympic bid. Int. J. Urban Reg. Res. 2000, 24, 439-458. [CrossRef]

40. Manzenreiter, W. Global sports commodity chains and Asia's new interregional division of labour. Int. J. Hist. Sport 2013, 30, 1299-1314. [CrossRef]

41. Preuss, H. The contribution of the FIFA World Cup and the Olympic Games to green economy. Sustainability 2013, 5, 3581-3600. [CrossRef]

42. Bondarenko, M.P. Assessment of the motivation factors for professional sport activity. Middle-East J. Sci. Res. 2013, 14, 1221-1225.

43. Inoue, Y.; Mahan, J.E., III; Kent, R.A. Enhancing the benefits of professional sport philanthropy: The roles of corporate ability and communication strategies. Sport Manag. Rev. 2013, 16, 314-325. [CrossRef]

44. Jewell, R.T.; Simmons, R.; Szymanski, S. Bad for business? The effects of hooliganism on English professional football clubs. J. Sports Econ. 2014, 15, 429-450. [CrossRef]

45. Shina, L.; Adam, B.; Chris, C. Modeling the economic impact of international tourism on the Chinese economy: A CGE analysis of the Beijing 2008 Olympics. Tour. Econ. 2011, 17, 279-303.

46. Agha, N. The economic impact of stadiums and teams: The case of minor league baseball. J. Sports Econ. 2013, 4, 227-252. [CrossRef]

47. Zeng, Q. Research of private capital's participation in the operations of China's public sports venues. In Future Computer, Communication, Control and Automation; AISC 119; Springer: Berlin, Germany; Heidelberg, Germany, 2012; pp. 163-168.

48. Apanavičienè, R.; Daugèlienè, A.; Baltramonaitis, T.; Maliene, V. Sustainability aspects of real estate development: Lithuanian case study of sports and entertainment arenas. Sustainability 2015, 7, 6497-6522. [CrossRef]

49. Lee, C.J. Effects of sport mega-events on city brand awareness and image: Using the 2009 world games in Kaohsiung as an example. Qual. Quant. 2014, 48, 1243-1256. [CrossRef]

50. Davies, L.E. Not in my back Yard! Sports stadia location and the property market. Area 2005, 37, $268-276$. [CrossRef]

51. Liu, T.; Wilkinson, S. Large-scale public venue development and the application of Public-Private Partnerships (PPPs). Int. J. Proj. Manag. 2014, 32, 88-100. [CrossRef]

52. Guha, S.; Birnholtz, J. Can you see me now?: Location, visibility and the management of impressions on foursquare. In Proceedings of the MobileHCI 15th international conference on Human-computer interaction with mobile devices and services, Munich, Germany, 27-30 August 2013; pp. 183-192. 
53. Speed, R.; Thompson, P. Determinants of sports sponsorship response. J. Acad. Mark. Sci. 2000, 28, $226-238$. [CrossRef]

54. Wishart, T.; Lee, S.P.; Cornwell, T.B. Exploring the relationship between sponsorship characteristics and sponsorship asking price. J. Sport Manag. 2012, 26, 335-349.

55. O'Reilly, N.; Lafrance Horning, D. Leveraging sponsorship: The activation ratio. Sport Manag. Rev. 2013, 16, 424-437. [CrossRef]

56. Bashiri, M.; Seyed-Ameri, M.H.; Moharramzadeh, M.; Hadi, H. Evaluation of sport sponsorship: As an element of sport marketing mix. Int. Rev. Bus. Res. Pap. 2010, 6, 57-74.

57. Walraven, M. Sports Sponsorship Effectiveness: Investigating Awareness, Sponsor Equity and Efficiency. Ph.D. Thesis, University of Groningen, Groningen, the Netherlands, 2013.

58. Moore, C.L.; Mowen, A.J.; Hickerson, B.D. Evaluating the effectiveness of corporate sponsorships at a minor league baseball park. Glob. Sport Bus. 2013, 1, 22-37.

59. Misener, K.; Doherty, A. In support of sport: Examining the relationship between community sport organizations and sponsors. Sport Manag. Rev. 2014, 17, 493-506. [CrossRef]

60. Saaty, T.L. The analytic network process: The organization and prioritization of complexity. In Decision Making with Dependence and Feedback; RWS Publications: Pittsburgh, PA, USA, 1996.

61. Hsu, C.T.; Liang, K.M.; Hsu, H.T.; Lo, K.Y.; Tsai, C.H. 2004-2011 practice retrospect and prospect of Taiwan's school sports statistics. Asian Sports Sci. 2013, 2, 13-22.

62. Gabus, A.; Fontela, E. World Problems an Invitation to Further Thought Within the Framework of DEMATEL; Battelle Geneva Research Centre: Geneva, Switzerland, 1972.

63. Fontela, E.; Gabus, A. The DEMATEL Observer; Battelle Institute. Geneva Research Center: Geneva, Switzerland, 1976.

64. Peng, K.H.; Tzeng, G.H. A hybrid dynamic MADM model for problems-improvement in economics and business. Technol. Econ. Dev. Econ. 2013, 19, 638-660. [CrossRef]

65. Chen, F.H.; Chi, D.J. Application of a new DEMATEL to explore key factors of China's corporate social responsibility: Evidence from accounting experts. Qual. Quant. 2015, 49, 135-154. [CrossRef]

66. Huang, K.W.; Huang, J.H.; Tzeng, G.H. New Hybrid Multiple Attribute Decision-Making Model for Improving Competence Sets: Enhancing a Company's Core Competitiveness. Sustainability 2016, 8, 175. [CrossRef]

67. Chen, F.H. Application of a hybrid dynamic MCDM to explore the key factors for the internal control of procurement circulation. Int. J. Prod. Res. 2015, 53, 2951-2969. [CrossRef]

68. Chen, F.H.; Tzeng, G.H.; Chang, C.C. Evaluating the enhancement of corporate social responsibility websites quality based on a new hybrid MADM model. Int. J. Inf. Technol. Decis. Mak. 2015, 14, 697-724. [CrossRef]

69. Opricovic, S. Multicriteria Optimization of Civil Engineering Systems; Faculty of Civil Engineering: Belgrade, Serbia, 1998.

70. Lu, M.T.; Lin, S.W.; Tzeng, G.H. Improving RFID adoption in Taiwan's healthcare industry based on a DEMATEL technique with a hybrid MCDM model. Decis. Support Syst. 2013, 56, 259-269. [CrossRef]

71. Opricovic, S.; Tzeng, G.H. Compromise solution by MCDM methods: A comparative analysis of VIKOR and TOPSIS. Eur. J. Oper. Res. 2004, 156, 445-455. [CrossRef]

72. Yeh, K.T. Taiwan's sports industry requirements for sustainable development. Natl. Sports Q. 2010, 39, $23-29$. (In Chinese)

(C) 2016 by the authors; licensee MDPI, Basel, Switzerland. This article is an open access article distributed under the terms and conditions of the Creative Commons Attribution (CC-BY) license (http:/ / creativecommons.org/licenses/by/4.0/). 